\title{
ANDRZEJ KuCIŃSKI
}

Akademia im. Jakuba z Paradyża w Gorzowie Wielkopolskim, Polska / The Jacob of Paradies University in Gorzów Wielkopolski, Poland

\section{Możliwości wykorzystania analizy płynności finansowej do oceny zdolności płatniczej oraz zagrożenia kontynuacii działania na podstawie danych zawartych w sprawozdaniach finansowych Zakładów Mięsnych Henryk Kania SA}

\section{Possibilities of using financial liquidity analysis to assess payment capacity and the threats for continuing operations on the basis of data included in the financial statements of Zakłady Mięsne Henryk Kania SA (Poland)}

\begin{abstract}
Streszczenie: Użytkownicy sprawozdań finansowych oczekują, aby informacje finansowe prezentowane $\mathrm{w}$ raportach finansowych były wiarygodne, rzetelne oraz prawdziwe. Sprawozdanie finansowe jest przedmiotem badania przez niezależnego biegłego rewidenta, który wydaje opinię o prawidłowości jego sporządzenia. W artykule za cel przyjęto przeprowadzenie oceny płynności finansowej Zakładów Mięsnych Henryk Kania SA oraz ustalenie tego, czy dane finansowe prezentowane w sprawozdaniu finansowym pozwalały jego użytkownikom wyznaczyć prawdziwy obraz zdolności płatniczej przedsiębiorstwa. W opracowaniu przyjęto założenie, że opinia niezależnego biegłego rewidenta zwiększa wiarygodność informacji finansowych prezentowanych w sprawozdaniu finansowym. Z przeprowadzonej analizy płynności finansowej ZM Henryk Kania wynikało, że problemy związane z utrzymaniem zdolności płatniczej w przedsiębiorstwie narastały w czasie, determinując ryzyko utraty zdolności do kontynuacji jego działalności. Odmowa wydania opinii z badania przez biegłego rewidenta budziła uzasadnione obawy użytkowników informacji, czy dane finansowe prezentowane przez spółkę w sprawozdaniu finansowym pozwalały nakreślić prawdziwy obraz zdolności płatniczej przedsiębiorstwa.
\end{abstract}

\footnotetext{
Abstract: Users of financial statements expect financial information presented in financial reports to be credible, reliable and true. The financial statements are audited by an independent auditor who issues an opinion on the correctness of its preparation. The aim of the article was to assess the financial liquidity of Zakłady Mięsne Henryk Kania SA and to ascertain whether the financial data presented in the financial statements allowed its users to determine the true picture of the payment capacity of the company. The study assumes that the independent auditor's opinion increases the reliability of the financial information presented in the financial statements. The conducted analysis of the financial liquidity of the company studied, showed that the problems related to maintaining the payment capacity in the enterprise grew in time, determining the risk of losing the ability to continue its operations. The refusal to issue an audit opinion by the auditor raised legitimate concerns of information users as to whether the financial data presented by the company in their financial statements made it possible to determine a true picture of the company's payment capacity.
} 
Słowa kluczowe: badanie sprawozdania finansowego, płynność finansowa, przedsiębiorstwo, rewizja finansowa, sprawozdanie finansowe

Keywords: audit of financial statement; enterprise; financial audit; financial liquidity; financial statement

Otrzymano: 27 listopada 2020

Received: 27 November 2020

Zaakceptowano: 5 lutego 2021

Accepted: 5 February 2021

\section{Sugerowana cytacja / Suggested citation:}

Kuciński, A. (2021). Możliwości wykorzystania analizy płynności finansowej do oceny zdolności płatniczej oraz zagrożenia kontynuacji działania na podstawie danych zawartych w sprawozdaniach finansowych Zakładów Mięsnych Henryk Kania SA. Prace Komisji Geografii Przemysłu Polskiego Towarzystwa Geograficznego, 35(1), 44-55. doi: 10.24917/20801653.351.3

\section{WSTĘP}

W gospodarce rynkowej podmioty gospodarcze muszą przede wszystkim zadbać o swoją płynność finansową. Wiąże się to z oceną płynności posiadanego majątku, analizą struktury aktywów jednostki, określeniem wielkości krótkoterminowego zadłużenia, a także ustaleniem zdolności do wypracowywania gotówki z działalności operacyjnej bądź też możliwości jej pozyskania z zewnętrznych źródeł finansowania.

Utrata płynności finansowej przez przedsiębiorstwo oznacza z reguły problemy finansowe, które nierozwiązane mogą doprowadzić do niewypłacalności. W czasach zwiększonej zmienności, w jakich przyszło funkcjonować współczesnym przedsiębiorstwom, a także trudnych do przewidzenia sytuacji kryzysowych, które mogą pojawić się na drodze przedsiębiorstwa, płynności finansowej nadaje się priorytetowe znaczenie.

Celem niniejszego artykułu jest przeprowadzenie oceny płynności finansowej Zakładów Mięsnych Henryk Kania SA w latach 2014-2018 oraz ustalenie tego, czy dane finansowe prezentowane w sprawozdaniu finansowym pozwalały jego użytkownikom wyznaczyć prawdziwy obraz zdolności płatniczej przedsiębiorstwa. W artykule przyjęto założenie, że opinia niezależnego audytora zwiększa wiarygodność informacji finansowych prezentowanych w sprawozdaniu finansowym, zaś użytkownicy informacji bazując na zweryfikowanych informacjach zmniejszają ryzyko niewłaściwej oceny sytuacji finansowej, w tym płynności finansowej.

W artykule do realizacji przyjętego celu jako metody badawcze wykorzystano: analizę literatury, analizę wskaźnikową danych finansowych, raporty Komisji Nadzoru Finansowego na temat wyrażonych opinii z badań rocznych sprawozdań finansowych emitentów papierów wartościowych, opinie z badania rocznych sprawozdań finansowych spółki Henryk Kania SA.

\section{SPRAWOZDANIE FINANSOWE JAKO ŹRÓDŁO INFORMACJI O PŁYNNOŚCI FINANSOWEJ - PRZEGLĄD LITERATURY}

W literaturze często podkreśla się, że sprawozdanie finansowe prezentuje uporządkowany zbiór informacji finansowych wykorzystywanych w procesie podejmowania decyzji finansowych (Sierpińska, Wędzki, 2002). Każdy element wchodzący w skład sprawozdania finansowego posiada unikatowy, ściśle określony przepisami prawa bilansowego zakres informacyjny, który zaspokaja potrzeby użytkowników informacji 
na temat funkcjonowania różnych obszarów działalności przedsiębiorstwa (Żukowska, Spoz, Zasuwa, 2016), w tym płynności finansowej.

Ocena sytuacji finansowej przedsiębiorstwa dokonywana jest najczęściej przez pryzmat rentowności, sprawności działania, zadłużenia oraz płynności finansowej. Biorąc pod uwagę złożoność procesów zachodzących w przedsiębiorstwie, trudno jest jednoznacznie wskazać najważniejszy obszar działania przedsiębiorstwa, który w największym stopniu przekładałby się na jego standing finansowy. Pomimo tego w literaturze przedmiotu często płynności finansowej nadaje się priorytetowe znaczenie, dominuje podejście, z którego wynika, że dla zapewnienia ciągłości działania przedsiębiorstwa niezbędne jest zachowanie zdolności płatniczej (Cicirko, 2010; Maślanka, 2019). Sama kategoria płynności finansowej cechuje się wielowątkowością, która znajduje swoje odzwierciedlenie w różnych ujęciach definicyjnych tego pojęcia. I tak płynność finansową można rozpatrywać w ujęciu majątkowym jako zdolność, sprawność przedsiębiorstwa do zamiany aktywów w środki pieniężne (Wędzki, 2003). W praktyce dominuje ujęcie majątkowo-kapitałowe, zgodnie z którym płynność finansowa to zdolność przedsiębiorstwa do regulowania bieżących zobowiązań. W podejściu tym podkreśla się istotną rolę płynnych aktywów stanowiących zabezpieczenie spłaty wymagalnych zobowiązań finansujących majątek przedsiębiorstwa (Kusak, 2006). Płynność finansowa może być również utożsamiana ze zdolnością do generowania przepływów pieniężnych, tzw. ujęcie dynamiczne płynności finansowej (Kusak, 2006), jako odpowiedź na krytykę wcześniej zaprezentowanych ujęć statycznych (m.in. Witczak, 2014). W tym miejscu należy podkreślić, iż płynność finansowa może być również rozpatrywana w ujęciu krótkoterminowym oraz długoterminowym. Z tego dualnego ujęcia wyłania się pojęcie wypłacalności, które utożsamiane jest ze zdolnością do spłaty wszystkich zobowiązań (Kuciński, 2018). Tym samym płynność finansowa przedsiębiorstwa może być rozpatrywana z różnych punktów widzenia. Do tego celu wykorzystywane są dane finansowe pochodzące ze sprawozdawczości finansowej przedsiębiorstwa.

Informacje pochodzące ze sprawozdawczości w ocenie sytuacji finansowej przedsiębiorstwa są użyteczne pod warunkiem, gdy są one zrozumiałe, przydatne, wiarygodne oraz porównywalne (Międzynarodowe Standardy Sprawozdawczości Finansowej..., 2007), a także gdy poszczególnych elementów sprawozdania finansowego nie traktuje się jako odrębnych, niezależnych od siebie części sprawozdania, lecz rozpatruje się je w powiązaniu, traktując poszczególne składniki sprawozdania jako spójną całość (Tokarski, 2009).

$\mathrm{Na}$ przestrzeni lat struktura sprawozdania finansowego ulegała zmianom, w tym zakres ujawnianych w nich informacji. Cechą charakterystyczną obecnego modelu sprawozdawczości finansowej jest wciąż koncentracja na przeszłości, to jest na ujmowaniu informacji w ujęciu ex post. W celu ograniczenia luki informacyjnej konieczne jest zwiększenie nacisku na raportowanie informacji w ujęciu ex ante. Jednocześnie, jak zauważa Rówińska, pomimo widocznych zmian zachodzących w sprawozdawczości finansowej niezmienny pozostał jej cel, którym jest rzetelne i zgodne z rzeczywistością informowanie o sytuacji finansowej i wyniku finansowym, co wymaga stosowania określonych norm w rachunkowości, w szczególności zasady prawdziwego i rzetelnego obrazu (true and fair view) (Rówińska, 2015).

Problem wiarygodności informacji finansowych zawartych w sprawozdaniu finansowym jest niezmiernie ważny, ale i aktualny. Liczne przykłady przedsiębiorstw, które dopuściły się fałszerstw sprawozdań finansowych, podważają zaufanie użytkowników 
sprawozdawczości do informacji finansowej, gdzie zjawisko zniekształceń sprawozdań finansowych ma charakter globalny. Potrzeba dysponowania rzetelnymi danymi finansowymi wymaga przeprowadzenia niezależnego audytu sprawozdania finansowego przez biegłego rewidenta, który pozwala zweryfikować wiarygodność prezentowanych informacji w raporcie finansowym. Jak słusznie zauważa Dobija, rolą audytora jest ograniczenie ryzyka wynikającego z dostarczenia niewłaściwych lub mających niską jakość informacji wspomagających procesy decyzyjne inwestorów (Dobija, 2014: 18). Pojęcie wiarygodności odnosi się bowiem do charakteru relacji pomiędzy podmiotami i może być utożsamiane z wysoką reputacją, prawością, rzetelnością przedsiębiorstwa. Jak zauważa Komorowski przedsiębiorstwa zabiegają o swoją wiarygodność w sposób celowy i zorganizowany, lecz percepcja i ocena tego stanu dokonywana jest przez jego otoczenie. Posiadanie wiarygodności przez przedsiębiorstwo jest niezbędnym warunkiem budowania właściwych relacji między podmiotami na rynku. Przyjmuje się a priori, iż każdy podmiot posiada wiarygodność do momentu, w którym zostanie ona utracona (Komorowski, 2012), stąd wizytówką jednostek gospodarczych, na podstawie której ocenia się ich wiarygodność ekonomiczną, jest sprawozdanie finansowe (Janik, 2012: 299).

Zagadnienie badania sprawozdania finansowego wchodzi w zakres rewizji finansowej (auditingu), będącej jedną z usług atestacyjnych. Termin rewizja (auditing) oznacza czynności badania ksiąg rachunkowych i sprawozdań finansowych przez biegłych rewidentów (auditors) (Marzec, Śliwa, 2012: 57). W myśl Międzynarodowych Standardów Badania opracowywanych przez Radę Międzynarodowych Standardów Rewizji Finansowej i Usług Atestacyjnych (ang. International Auditing and Assurance Standards Board, IAASB) działającą w ramach Międzynarodowej Federacji Księgowych (ang. International Federation of Accountants) celem badania jest zwiększenie stopnia zaufania użytkowników do sprawozdania finansowego (Międzynarodowy Standard Badania 200, 2009: §3) poprzez wydanie opinii, w której biegły rewident stwierdza, czy sprawozdanie finansowe zostało sporządzone zgodnie z zasadami rachunkowości oraz czy prezentuje rzetelny i jasny obraz sytuacji majątkowej i finansowej przedsiębiorstwa (Włodarczyk, Białek-Jaworska, 2018). Jak słusznie zauważają Chorowski oraz Kawalec zasadniczym założeniem koncepcji rewizji sprawozdania finansowego według Międzynarodowych Standardów Badania jest orientacja na ryzyka, na które narażona jest jednostka, mogące mieć wpływ na istotne zniekształcenia w jej sprawozdaniu (Chorowski, Kawalec, 2017: 88), gdzie zniekształcenie to różnica między kwotą, klasyfikacją, prezentacją lub ujawnieniem pozycji wykazywanej w sprawozdaniu finansowym a kwotą, klasyfikacją, prezentacją lub ujawnieniem pozycji, które wymagają wykazania zgodnie z mającymi zastosowanie ramowymi założeniami sprawozdawczości finansowej (Międzynarodowy Standard Badania 450, 2009: 3, §4). Zniekształcenie sprawozdania finansowego może być następstwem oszustwa lub popełnionego błędu. Marzec oraz Śliwa wskazują, że „cechą odróżniającą oszustwo od błędu jest to, czy działania, w wyniku których powstało zniekształcenie sprawozdań finansowych, są zamierzone czy niezamierzone" (Marzec, Śliwa, 2012: 134). Zgodnie z Międzynarodowym Standardem Badania 240 oszustwo to zamierzone działanie pracowników, członków zarządu, organów nadzoru, osób trzecich, którzy poprzez celowe wprowadzane w błąd, kłamstwo, zatajanie faktów zmierzają do uzyskania nieuzasadnionej lub niezgodnej z prawem korzyści (Międzynarodowy Standard Badania 240, 2009: §11). Z kolei błąd to niezamierzone działania spowodowane niewiedzą, pomyłkami, przeoczeniem lub niewłaściwą interpretacją, które 
prowadzą do nieprawidłowości występujących w sprawozdaniu finansowym (Marzec, Śliwa, 2012). W wyniku przeprowadzonego badania i na podstawie zebranych dowodów biegły rewident formułuje w sprawozdaniu z badania opinię na temat informacji prezentowanych w sprawozdaniu finansowym, która to opinia może być: opinią bez zastrzeżeń, opinią z zastrzeżeniami, opinią negatywną, bądź też audytor może odmówić wyrażenia opinii (Międzynarodowy Standard Badania 705, 2016: §6-14). Wydanie opinii o sprawozdaniu finansowym bez zastrzeżeń pozwala użytkownikom raportów finansowych uzyskać wystarczającą pewność, że sprawozdanie nie zawiera istotnych zniekształceń informacji finansowych, ale jak słusznie zauważa Kutera zaudytowane sprawozdanie finansowe nie daje stuprocentowej pewności, że jest ono wolne od wszelakich nieprawidłowości (Kutera, 2008). Podobnego zdania jest Górka, który jest przekonany o tym, że każde sprawozdanie finansowe zawiera pewne nieprawidłowości, stąd od biegłego rewidenta wymaga się przyjęcia określonych założeń co do poziomu istotności nieprawidłowości, do którego progu lub granicy owe nieprawidłowości traktuje się jako nieistotne. Oznacza to, że założony poziom istotności nie wpływa na użyteczność informacji płynących ze sprawozdania finansowego, lecz pozwala przyjąć, że sprawozdanie finansowe jest wolne od istotnych zniekształceń, choć nie daje absolutnej pewności w tym względzie (Górka, 2005). Konsekwencją takiego podejścia są towarzyszące badaniu sprawozdań finansowych ryzyka, będące funkcją ryzyka istotnego zniekształcenia (ryzyko kontroli, ryzyko nieodłączne) oraz ryzyka przeoczenia, a które to ryzyka należy minimalizować (Marzec, Śliwa, 2012). Zatem audyt sprawozdania finansowego pozwala zwiększyć użyteczność informacji wykorzystywanych w procesach decyzyjnych, w tym tych podejmowanych przez inwestorów giełdowych o kierunkach alokacji kapitału.

\section{METODYKA BADANIA}

Badanie przeprowadzono na podstawie spółki Zakłady Mięsne Henryk Kania SA. Historia tych zakładów rozpoczęła się w 1990 roku od założenia rodzinnego przedsiębiorstwa, które na przestrzeni kolejnych kilku lat było dynamicznie rozwijane. $\mathrm{Na}$ GPW w Warszawie spółka pojawiła się dzięki przeprowadzonej fuzji z notowaną już na parkiecie spółką IZNS Iława. Działalności przedsiębiorstwa od zawsze towarzyszył problem nadmiernego zadłużenia. Poważne problemy nadeszły po odmowie wydania opinii z badania sprawozdania finansowego. W czerwcu 2019 roku wobec spółki wdrożono przyspieszone postępowanie układowe, powołując nadzorcę sądowego do przeprowadzenia restrukturyzacji przedsiębiorstwa. W październiku 2019 roku zawieszono notowania spółki na giełdzie, zaś w 2020 roku ogłoszono upadłość likwidacyjną przedsiębiorstwa.

Realizację założonych celów osiągnięto w ten sposób, że na początku badania przedstawiono informacje na temat liczby wydanych opinii z zastrzeżeniami, negatywnych lub odmową wyrażenia opinii dla rocznych sprawozdań finansowych emitentów papierów wartościowych na rynku regulowanym GPW w Warszawie za lata obrotowe 2014-2018 w celu zobrazowania skali nieprawidłowości w publikowanych sprawozdaniach finansowych spółek. W grupie emitentów, którym odmówiono wyrażenia opinii były Zakłady Mięsne Henryk Kania SA, tym samym w kolejnym etapie badań przeprowadzono analizę płynności finansowej w celu zobrazowania zdolności płatniczej przedsiębiorstwa. Do pomiaru płynności finansowej wykorzystano wybrane 
wskaźniki finansowe. W pierwszej kolejności wykorzystano wskaźniki bieżącej płynności finansowej, podwyższonej płynności finansowej, gotówkowej płynności finansowej, na podstawie których dokonano oceny krótkoterminowej zdolności płatniczej. W dalszej części na podstawie reguł finansowych, wskaźnika ogólnego poziomu zadłużenia oraz trwałości struktury finansowania oceniono długoterminową płynność finansową. Statyczny obraz płynności finansowej uzupełniono o analizę rachunku przepływów pieniężnych wraz z wyznaczeniem wariantów przepływów środków pieniężnych. Rachunek przepływów środków pieniężnych to element sprawozdania finansowego, który obrazuje wpływy i wydatki obejmujące trzy rodzaje działalności: operacyjną, inwestycyjną oraz finansową. Strumienie pieniężne z poszczególnych rodzajów działalności osiągane przez jednostkę tworzy 8 możliwych konfiguracji determinujących sytuację finansową przedsiębiorstwa, w tym płynność finansową.

Tabela 1 . Warianty przepływów pieniężnych

\begin{tabular}{|l|c|c|c|c|c|c|c|c|}
\hline \multirow{2}{*}{\multicolumn{1}{c|}{ Przepływy pieniężne }} & \multicolumn{9}{c|}{ Warianty } \\
\cline { 2 - 17 } & 1 & 2 & 3 & 4 & 5 & 6 & 7 & 8 \\
\hline operacyjne & + & + & + & + & - & - & - & - \\
\hline inwestycyjne & + & - & + & - & + & - & + & - \\
\hline finansowe & + & - & - & + & + & + & - & - \\
\hline
\end{tabular}

Źródło: opracowanie własne

I tak wariant pierwszy, w którym wszystkie realizowane przepływy są dodatnie, charakteryzuje przedsiębiorstwa akumulujące gotówkę w związku z planowanymi inwestycjami lub przejęciami. Wariant drugi jest realizowany przez przedsiębiorstwa, które ostrożnie wykorzystują kapitały obce w finansowaniu działalności i jest oceniany pozytywnie, gdy nadwyżka operacyjna pozwalała w pełni pokryć wydatki w ramach działalności inwestycyjnej i finansowej. Z kolei wariant trzeci jest charakterystyczny dla przedsiębiorstw przechodzących głębokie procesy restrukturyzacyjne. Wariant czwarty dotyczy przedsiębiorstw o dobrej kondycji finansowej, znajdujących się na szybkiej ścieżce rozwoju, które wykorzystują do tego zarówno przepływy operacyjne, jak i z działalności finansowej. Warianty, w których przedsiębiorstwo uzyskuje ujemne przepływy z działalności operacyjnej należy zawsze oceniać negatywnie (warianty 5-8), gdyż w dobrze prosperującej jednostce gospodarczej to działalność podstawowa powinna generować gotówkę. Poważne problemy finansowe przedsiębiorstwa opisują w szczególności warianty 7-8. Wariant 7 dotyczy podmiotów, w których problemy mają charakter długotrwały, a próba wyjścia z trudnej sytuacji poprzez upłynnienie aktywów trwałych przedsiębiorstwa nie zawsze jest dobrym rozwiązaniem. Z kolei wariant 8 ukazuje niebezpieczeństwo z zachowaniem płynności finansowej, często wariant ten poprzedza upadłość przedsiębiorstwa.

Ostatnią część badania stanowił przegląd wydanych opinii z badania sprawozdań finansowych, które stanowiły podstawę do oceny tego czy dane finansowe prezentowane w sprawozdaniu finansowym Henryk Kania SA pozwalały jego użytkownikom ustalić rzeczywisty obraz płynności finansowej oraz ocenić zdolność do kontynuacji działania. 


\section{WIARYGODNOŚĆ SPRAWOZDANIA FINANSOWEGO ORAZ OCENA ZDOLNOŚCI PŁATNICZEJ SPÓŁKI HENRYK KANIA SA}

Sprawozdanie finansowe „kreowane” przez system rachunkowości przedsiębiorstwa zawiera w sobie dane finansowe o określonym zakresie tematycznym, które pozwala jego użytkownikom przede wszystkim na zapoznanie się z sytuacją majątkową i finansową firmy. Na podstawie sprawozdań finansowych użytkownicy, w tym zwłaszcza inwestorzy giełdowi, podejmują swoje decyzje. Tym samym ważne jest z punktu widzenia procesu podejmowania decyzji, aby informacje pochodzące ze sprawozdawczości finansowej były przede wszystkim wiarygodne.

Zgodnie z rozporządzeniem Ministra Finansów w sprawie informacji bieżących i okresowych przekazywanych przez emitentów papierów wartościowych oraz warunków uznawania za równoważne informacji wymaganych przepisami prawa państwa niebędącego państwem członkowskim emitenci papierów wartościowych zobowiązani są do tego, aby raport roczny oraz skonsolidowany raport roczny spółki obejmował m.in. sprawozdanie niezależnego biegłego rewidenta $\mathrm{z}$ badania sprawozdania finansowego (Rozporządzenie Ministra Finansów... 2018: art. 70 ust. 1 pkt. 9, art. 71 ust. 1 pkt. 9). Opinia biegłego rewidenta sporządzona z badania pozwala użytkownikom informacji ocenić jakość danych finansowych prezentowanych przez zarząd przedsiębiorstwa. $\mathrm{Z}$ zestawionych $\mathrm{w}$ tabeli $\mathrm{nr} 2$ informacji na temat liczby wydanych opinii z zastrzeżeniami, negatywnych lub z odmową wyrażenia opinii dla rocznych sprawozdań finansowych emitentów papierów wartościowych notowanych na rynku regulowanym GPW w Warszawie w latach 2014-2018 wynika, iż odsetek przypadków, w których audytorzy sformułowali zastrzeżenia obejmował od 7\% do 8\% ogółu liczby emitentów. Największa liczba przypadków wydanych opinii z zastrzeżeniami dotyczyła 2015 roku, zaś najmniejsza 2017 roku, z kolei liczba odmów wydania opinii przez biegłego rewidenta w poszczególnych latach była podobna i obejmowała od 8 do 11 przypadków. W 2018 roku w grupie emitentów, którym odmówiono wyrażenia opinii były Zakłady Mięsne

Tabela 2. Liczba opinii z zastrzeżeniami, negatywnych lub odmową wyrażenia opinii dla rocznych sprawozdań finansowych emitentów papierów wartościowych na rynku regulowanym GPW w Warszawie za lata obrotowe 2014-2018

\begin{tabular}{|l|c|c|c|c|c|}
\hline \multirow{2}{*}{ Liczba emitentów } & \multicolumn{5}{c|}{ LATA } \\
\cline { 2 - 6 } & 2014 & 2015 & 2016 & 2017 & 2018 \\
\hline Opinie z zastrzeżeniami & 20 & 29 & 22 & 19 & 20 \\
\hline Odmowy wyrażenia opinii & 10 & 8 & 11 & 10 & 9 \\
\hline Opinie negatywne & 0 & 0 & 0 & 1 & 1 \\
\hline Razem & 30 & 37 & 33 & 30 & 30 \\
\hline $\begin{array}{l}\text { Liczba emitentów z rynku regulowanego na } \\
\text { koniec roku }\end{array}$ & 441 & 455 & 456 & 456 & 441 \\
\hline $\begin{array}{l}\text { Udział opinii z zastrzeżeniami, bez wyrażonych } \\
\text { opinii oraz negatywnych w liczbie emitentów } \\
\text { na koniec roku w \% }\end{array}$ & $7 \%$ & $8 \%$ & $7 \%$ & $7 \%$ & $8 \%$ \\
\hline
\end{tabular}

Źródło: opracowanie własne na podstawie raportów KNF Nadzór nad sprawozdawczościa finansowq emitentów papierów wartościowych prowadzony w 2017 r.; 2018 r., Urząd Komisji Nadzoru Finansowego, Warszawa 2018-2020. Pozyskano z https://www.knf.gov.pl/publikacje_i_opracowania (dostęp 12.05.2020), Nadzór nad wypełnianiem obowiązków informacyjnych przez emitentów papierów wartościowych prowadzony w 2019 roku, Komisja Nadzoru Finansowego, Warszawa 2020. Pozyskano z https://www.knf.gov.pl/publikacje_i_opracowania (dostęp 14.05.2020) 
Henryk Kania SA. W całym badanym okresie wydano dwie negatywne opinie z badania, w których audytor stwierdził, iż sprawozdanie finansowe spółki nie przedstawia rzetelnego i jasnego obrazu sytuacji majątkowej i finansowej oraz wyniku finansowego.

Biorąc pod uwagę to, iż w grupie przedsiębiorstw, które otrzymały opinie z zastrzeżeniami bądź też biegły rewident odmówił wyrażenia opinii z badania rocznego sprawozdania finansowego znalazły się Zakłady Mięsne Henryk Kania SA przedmiotem dalszych badań była płynność finansowa przedsiębiorstwa.

Ocenę zdolności płatniczej przedsiębiorstwa dokonano na podstawie wybranych wskaźników płynności finansowej odzwierciedlając różne ujęcia płynności finansowej. Na podstawie statycznych wskaźników płynności finansowych wyznaczonych w tabeli nr 3 wynika, iż Zakłady Mięsne Henryk Kania SA wykazywały w badanym okresie pogarszającą się zdolność do regulowania bieżących zobowiązań. W 2014 roku aktywa obrotowe przewyższały krótkoterminowe zobowiązania w 69\%, zaś na koniec 2018 roku jedynie w 13\%. Problemy z zachowaniem zdolności płatniczej do regulowania bieżących zobowiązań widoczne były w 2017 roku, gdzie wartość wskaźnika bieżącej płynności była wyraźnie niższa niż 1 , wartość normatywna wskaźnika powinna być wyraźnie większa od jedności. Poziom wskaźnika bieżącej płynności poniżej 1 jednocześnie informował o ujemnym kapitale obrotowym, co oznaczało, że część majątku trwałego była finansowana krótkoterminowymi źródłami determinując wzrost ryzyka utraty płynności finansowej. Podobny obraz płynności finansowej wyłania się na podstawie wskaźnika podwyższonej płynności, którego najwyższy poziom zaobserwowano w 2014 roku. Wskaźnik podwyższonej płynności pozwala dokładniej określić zdolność płatniczą przedsiębiorstwa wskazując na poziom pokrycia bieżących zobowiązań aktywami obrotowymi pomniejszonymi o zapasy i rozliczenia międzyokresowe, to jest po wyeliminowaniu najmniej płynnych składników tworzących majątek obrotowy przedsiębiorstwa. W latach 2017-2018 wartość wskaźnika była poniżej 1, w tym okresie zdolność przedsiębiorstwa do bieżącego regulowania swoich zobowiązań była wyraźnie niższa. Z kolei poziom wskaźnika płynności gotówkowej wskazywał, że przedsiębiorstwo utrzymywało skrajnie niski poziom środków pieniężnych, tym samym zdolność przedsiębiorstwa do natychmiastowej spłaty zobowiązań praktycznie nie istniała. Przyrównując wielkości wskaźników statycznej płynności finansowej do wielkości średnich w gospodarce (np. do wyników finansowych podmiotów gospodarczych - Główny Urząd Statystyczny) bądź wielkości sektorowych (sektorowe wskaźniki finansowe SKwP) to okazuje się, że były one poniżej wielkości zalecanych. Ogólnie można stwierdzić, że działalności ZM Henryk Kania towarzyszyła niska zdolność do spłaty bieżących zobowiązań.

Tabela 3. Wybrane wskaźniki krótkoterminowej (statycznej) płynności finansowej Zakładów Mięsnych Henryk Kania SA w latach 2014-2018

\begin{tabular}{|l|c|c|c|c|c|}
\hline \multicolumn{1}{|c|}{ Wskaźnik } & 2014 & 2015 & 2016 & 2017 & 2018 \\
\hline bieżącej płynności & 1,69 & 1,60 & 1,45 & 0,89 & 1,13 \\
\hline podwyższonej płynności & 1,33 & 1,30 & 1,24 & 0,67 & 0,85 \\
\hline gotówkowej płynności & 0,00 & 0,01 & 0,00 & 0,00 & 0,00 \\
\hline
\end{tabular}

Źródło: opracowanie własne

Wskaźniki długoterminowej płynności finansowej zobrazowane w tabeli nr 4 wskazywały również na pogarszającą się zdolność ZM Henryk Kania do spłaty zobowiązań 
ogółem. Malejący poziom wskaźnika pokrycia aktywów trwałych kapitałem własnym oraz brak spełnienia podstawowej reguły finansowej w latach 2017-2018, to sygnał o pogarszającej się sytuacji finansowej przedsiębiorstwa oraz źle ukształtowanej strukturze kapitałów w spółce. Co więcej spełnienie łagodniejszej reguły finansowania było dla badanego przedsiębiorstwa również problematyczne. W latach 2017-2018 wskaźnik pokrycia aktywów trwałych kapitałem stałym wyraźnie uległ zmniejszeniu, w 2017 był on poniżej 1 co oznaczało, że część aktywów trwałych była finansowana krótkoterminowymi źródłami kapitału, zaś w 2018 roku wielkość wskaźnika była nieznacznie powyżej 1. Jednocześnie opisywanej sytuacji towarzyszył wzrost poziomu zadłużenia oraz obniżenie trwałości struktury finansowania i było to o tyle niepokojące, że niekorzystne zmiany zachodzące w strukturze kapitałów negatywnie rzutowały na bezpieczeństwo finansowe, w tym płynność finansową przedsiębiorstwa.

Tabela 4. Wybrane wskaźniki długoterminowej płynności finansowej Zakładów Mięsnych Henryk Kania SA w latach 2014-2018

\begin{tabular}{|l|c|c|c|c|c|}
\hline \multicolumn{1}{|c|}{ Wskaźnik } & 2014 & 2015 & 2016 & 2017 & 2018 \\
\hline $\begin{array}{l}\text { pokrycia aktywów trwałych } \\
\text { kapitałem własnym }\end{array}$ & 1,03 & 1,19 & 1,29 & 0,56 & 0,70 \\
\hline $\begin{array}{l}\text { pokrycia aktywów trwałych } \\
\text { kapitałem stałym }\end{array}$ & 1,77 & 1,86 & 1,89 & 0,88 & 1,15 \\
\hline ogólnego poziomu zadłużenia & 0,64 & 0,64 & 0,67 & 0,72 & 0,70 \\
\hline trwałości struktury finansowania & 0,61 & 0,57 & 0,49 & 0,45 & 0,50 \\
\hline
\end{tabular}

Źródło: opracowanie własne

Z punktu widzenia oceny płynności finansowej równie ważną co bilans częścią sprawozdania finansowego jest rachunek przepływów pieniężnych. Na podstawie zestawienia (tabela 5) wynika, że Zakłady Mięsne Henryk Kania SA wykazywały w badanym okresie poważne problemy z generowaniem gotówki ze swojej podstawowej działalności. Negatywny wydźwięk uzyskiwanych przepływów z działalności operacyjnej pogłębia to, że badane przedsiębiorstwo w rachunku zysków i strat wykazywało zyski, które nie znalazły swojego potwierdzenia w rzeczywistości, to jest w przepływach pieniężnych. Niedobory środków pieniężnych przedsiębiorstwo uzupełniało głównie poprzez emisję dłużnych instrumentów finansowych (obligacji) czy też zaciąganie

Tabela 5. Przepływy środków pieniężnych oraz warianty wartości przepływów pieniężnych Zakładów Mięsnych Henryk Kania SA w latach 2014-2018

\begin{tabular}{|l|r|r|r|r|r|}
\hline \multicolumn{1}{|c|}{ Wyszczególnienie } & 2014 & 2015 & 2016 & 2017 & 2018 \\
\hline Przepływy z działalności operacyjnej & -713 & -23187 & -29663 & 38 & 48213 \\
\hline $\begin{array}{l}\text { Przepływy z działalności } \\
\text { inwestycyjnej }\end{array}$ & -9716 & -5633 & -25720 & -9899 & -3403 \\
\hline Przepływy z działalności finansowej & 10361 & 31363 & 53465 & 9455 & -44011 \\
\hline $\begin{array}{l}\text { Wariant przepływów środków } \\
\text { pieniężnych* }\end{array}$ & 6 & 6 & 6 & 4 & 2 \\
\hline
\end{tabular}

* wariant przepływów pieniężnych wynika ze struktury strumieni pieniężnych z poszczególnych rodzajów działalności osiąganych przez przedsiębiorstwo, które wyodrębnia się w ramach modelu 8 przypadków przepływów środków pieniężnych

Źródło: opracowanie własne 
kredytów bankowych. Takie postępowanie nie rozwiązywało problemów w spółce, wręcz odwrotnie przysporzyło dodatkowych kłopotów związanych z rosnącym zadłużeniem i kosztami jego obsługi (odsetek). Utrzymywany układ przepływów pieniężnych w przedsiębiorstwie (wariant 6) okazał się być bardzo ryzykowanym, negatywnie przekładał się na płynność finansową przedsiębiorstwa. Realizowane przepływy środków pieniężnych ze wszystkich rodzajów działalności prowadziły do odpływu środków pieniężnych, a to jeszcze bardziej zwiększało ryzyko utraty płynności finansowej.

Sprawozdania finansowe, na podstawie których dokonano oceny płynności finansowej Zakładów Mięsnych Henryk Kania SA, podlegały badaniu przez biegłego rewidenta. Z przeglądu wydanych opinii wynikało, że sprawozdanie finansowe przedsiębiorstwa w latach 2014-2017 przedstawiało rzetelny i jasny obraz sytuacji finansowej przedsiębiorstwa, wyniki finansowe jednostki, a także że zostało sporządzone zgodnie z obowiązującymi zasadami rachunkowości oraz o prawidłowości prowadzonych ksiąg rachunkowych. Użytkownik sprawozdania finansowego, na podstawie wydanych opinii, nie miał żadnych podstaw do tego, aby sądzić, że sprawozdanie finansowe nie przedstawiało rzeczywistego obrazu czy też nie zostało sporządzone zgodnie z zasadami rachunkowości. Biegły rewident sporządzając opinię o badanym sprawozdaniu finansowym za 2017 rok wskazał na dwa ryzyka istotnego zniekształcenia, które ostatecznie nie wypłynęły na zmianę wydania pozytywnej opinii przez audytora. W swym raporcie audytor wskazał przede wszystkim na rosnące ryzyko utraty płynności finansowej przez spółkę w związku ze znacznym przyrostem zobowiązań krótkoterminowych. Kluczowym momentem w historii działalności spółki okazał się być wydany raport z badania za 2018 rok, w którym to firma audytorska odmówiła wydania opinii z badania sprawozdania finansowego. Fakt odstąpienia od wyrażenia opinii przez biegłego rewidenta podważało zaufanie użytkowników sprawozdania finansowego do danych finansowych wykazywanych w raporcie finansowym przez spółkę, ale jednocześnie budziło uzasadnione podejrzenie na temat rzetelności prowadzonych ksiąg rachunkowych przez spółkę Henryk Kania. Biegły rewident zakwestionował m.in.: prawidłowość wykazywanych niektórych pozycji w bilansie, zakładane korzyści ekonomiczne z tytułu posiadania pewnych wierzytelności czy należności, możliwość przedłużenia lub pozyskania źródeł finansowania. Trafność wydanych zastrzeżeń do sprawozdania znalazło swoje odzwierciedlenie w sprawozdaniu rocznym za 2019 rok, w którym spółka wykazała stratę na poziomie ponad 888 mln zł, która przełożyła się na ujemne kapitały własne. Trwała utrata płynności finansowej, brak możliwości pozyskania źródeł finansowania doprowadziły do upadłości spółki. To potwierdza tezę, że opinia biegłego rewidenta wspomaga decyzje podejmowane przez użytkowników informacji.

\section{PODSUMOWANIE}

Kapitał powierzony emitentom papierów wartościowych przez inwestorów może być bezpowrotnie utracony na skutek ogłoszenia niewypłacalności przedsiębiorstwa, z którą mamy do czynienia wówczas, kiedy utraci ono trwałą zdolność do regulowania swoich zobowiązań finansowych. W praktyce często stan ten poprzedzają problemy z zachowaniem bieżącej płynności finansowej.

Z analizy płynności finansowej ZM Henryk Kania wynikało, że problemy związane z utrzymaniem zdolności płatniczej w przedsiębiorstwie narastały w czasie, 
determinując ryzyko utraty zdolności do kontynuacji jego działalności. Przykład Zakładów Mięsnych Henryk Kania SA dowodzi, iż nierozwiązane problemy z zachowaniem płynności finansowej mogą doprowadzić do upadłości przedsiębiorstwa. Wydaje się, iż nieocenionym wsparciem dla inwestorów w procesie podejmowania decyzji mogą być opinie biegłych rewidentów z badania sprawozdań finansowych, które zwiększają wiarygodność informacji finansowych dostarczanych przez spółkę. Odmowa wydania opinii z badania sprawozdania finansowego, jaka miała miejsce w przypadku spółki Henryk Kania, ograniczała zaufanie inwestorów do spółki, a jednocześnie oznaczała, że użytkownicy niezaudytowanych pozytywnie sprawozdań finansowych nie byli w stanie ustalić w sposób wiarygodny zdolności płatniczej przedsiębiorstwa, a co za tym idzie zagrożenia jego niewypłacalności, które determinowało ryzyko inwestycyjne posiadanych udziałów w spółce.

\section{Literatura \\ References}

Chorowski, M., Kawalec, J. (2017). Planowanie jako podstawa optymalizacji procesu badania sprawozdań finansowych zgodnie z międzynarodowymi standardami rewizji finansowej. Studia Ekonomiczne. Uniwersytet Ekonomiczny w Katowicach, 341, 82-98.

Cicirko, T. (red.). (2010). Podstawy zarzadzania płynnościa finansowa przedsiębiorstwa. Warszawa: Szkoła Główna Handlowa. Oficyna Wydawnicza.

Dobija, D. (2014). Audyt finansowy we współczesnych systemach społecznych. Funkcje i praktyka. Warszawa: Oficyna Wolters Kluwer.

Górka, Ł. (2005). Istotność w badaniu sprawozdania finansowego. Zeszyty Naukowe Akademii Ekonomicznej w Krakowie, 674, 33-44.

Janik, W. (2012). Wiarygodność przedsiębiorstwa w świetle sprawozdań finansowych. W: H. Żukowska, W. Janik (red.), Audyt zewnętrzny sprawozdania finansowego a wiarygodność przedsiębiorstwa. Lublin: Wydawnictwo KUL.

Komorowski, J. (2012). Wiarygodność przedsiębiorstwa - istota, odmiany i metody badania. W: H. Żukowska, W. Janik (red.), Audyt zewnętrzny sprawozdania finansowego a wiarygodność przedsiębiorstwa. Lublin: Wydawnictwo KUL.

Kuciński, A. (2018). Wypłacalność przedsiębiorstwa z punktu widzenia płynności finansowej i zadłużenia. Przedsiębiorczość i Zarządzanie, 19(4/1), 119-131.

Kutera, M. (2008). Rola audytu finansowego w wykrywaniu przestępstw gospodarczych. Warszawa: Wydawnictwo Difin.

Kusak, A. (2006). Płynność finansowa. Analiza i sterowanie. Warszawa: Wydawnictwo Naukowe Wydziału Zarządzania Uniwersytetu Warszawskiego.

Marzec, J., Śliwa, J. (2012). Audyt finansowy w jednostkach gospodarczych. Teoria i praktyka. Procedury, metody i techniki badania sprawozdań finansowych. Warszawa: Wydawnictwo Naukowe Wydziału Zarządzania Uniwersytetu Warszawskiego.

Maślanka, T. (2019). Płynność finansowa determinanta zdolności kontynuacji działalności przedsiębiorstwa. Warszawa: Wydawnictwo CeDeWu.

Międzynarodowe Standardy Sprawozdawczości Finansowej (MSSF) 2007. Obejmujące Międzynarodowe Standardy Sprawozdawczości Finansowej (MSSF) oraz Interpretacje według stanu na dzień 1 stycznia 2007 r. Kompletny tekst Międzynarodowych Standardów Sprawozdawczości Finansowej obowiązujących na dzień 1 stycznia 2007 r. (2007). T. 1. Warszawa: Stowarzyszenie Księgowych w Polsce.

Międzynarodowy Standard Badania 200. (2009). Ogólne cele niezależnego biegłego rewidenta oraz przeprowadzanie badania zgodnie z międzynarodowymi standardami badania. IFAC.

Międzynarodowy Standard Badania 240. (2009). Odpowiedzialność biegłego rewidenta podczas badania sprawozdań finansowych dotyczaca oszustw. IFAC.

Międzynarodowy Standard Badania 450. (2009). Ocena zniekształceń zidentyfikowanych podczas badania. IFAC. 
Międzynarodowy Standard Badania 705. (2016). Modyfikacje opinii w sprawozdaniu niezależnego biegłego rewidenta. IFAC.

Nadzór nad sprawozdawczościq finansowa emitentów papierów wartościowych prowadzony w 2017, 2018 r. (2018-2019). Warszawa: Urząd Komisji Nadzoru Finansowego. Pozyskano z https://www.knf.gov.pl/publikacje_i_opracowania (dostęp 12.05.2020).

Nadzór nad wypetnianiem obowiq̨zów informacyjnych przez emitentów papierów wartościowych prowadzony w 2019 roku. (2020). Warszawa: Komisja Nadzoru Finansowego. Pozyskano z https://www.knf.gov.pl/publikacje_i_opracowania (dostęp 14.05.2020).

Rozporządzenie Ministra Finansów z dnia 29 marca 2018 roku w sprawie w sprawie informacji bieżacych i okresowych przekazywanych przez emitentów papierów wartościowych oraz warunków uznawania za równoważne informacji wymaganych przepisami prawa państwa niebędq̨cego państwem członkowskim. Dz.U. 2018 poz. 757.

Rówińska, M. (2015). Kierunki zmian sprawozdawczości finansowej jednostek gospodarczych na tle polskich i międzynarodowych regulacji rachunkowości. Studia Ekonomiczne. Uniwersytet Ekonomiczny w Katowicach, 240, 114-124.

Sierpińska, M., Wędzki, D. (2002). Zarzq̨dzanie płynnościq finansowq w przedsiębiorstwie. Warszawa: Wydawnictwo Naukowe PWN.

Tokarski, M. (2009). Sprawozdanie finansowe - niedoskonałe źródło informacji o sytuacji finansowej przedsiębiorstwa. Przedsiębiorczość-Edukacja, 5, 176-186.

Wędzki, D. (2003). Strategie płynności finansowej przedsiębiorstwa. Przepływy pieniężne a wartość dla właścicieli. Kraków: Oficyna Ekonomiczna.

Witczak, I. (2014). Płynność finansowa jako miara sprawności funkcjonowania firm farmaceutycznych. Studia Ekonomiczne. Uniwersytet Ekonomiczny w Katowicach, 201, 415-423.

Włodarczyk, A., Białek-Jaworska, A. (2018). Determinanty zastrzeżeń w opinii biegłego rewidenta z badania sprawozdania finansowego. Acta Universitatis Lodziensis. Folia Oeconomica, 5, 157-182.

Żukowska, H., Spoz, A., Zasuwa, G. (red.). (2016). Sprawozdawczość w procesie zarządzania i oceny działalności przedsiębiorstwa. Lublin: Wydawnictwo KUL.

Andrzej Kuciński, dr, adiunkt, Akademia im. Jakuba z Paradyża w Gorzowie Wielkopolskim, Wydział Ekonomiczny, Katedra Zarządzania Finansami. Zainteresowania badawcze autora koncentrują się przede wszystkim wokół problematyki związanej z płynnością finansową przedsiębiorstw, kondycją finansową przedsiębiorstw, modeli predykcji bankructwa.

Andrzej Kuciński, PhD, he is an assistant professor in the Department of Financial Management at the Faculty of Economics at the Jacob of Paradies University in Gorzów Wielkopolski. The author's research interests focus primarily on issues related to the financial liquidity of enterprises, financial condition of enterprises, bankruptcy prediction models.

ORCID: https://orcid.org/0000-0002-8988-8872

\section{Adres/address:}

Akademia im. Jakuba z Paradyża w Gorzowie Wielkopolskim

Wydział Ekonomiczny

Katedra Zarządzania Finansami

ul. Fryderyka Chopina 52

66-400 Gorzów Wielkopolski, Polska

e-mail: akucinski@ajp.edu.pl 